\title{
EVALUATION OF BIOLOGICAL INDIFFERENCE OF NEWER DENTAL LIGHT-CURED MATERIALS BASED ON OUTCOMES OF CLINICAL AND MORPHOLOGICAL STUDIES IN EXPERIMENT
}

\author{
V.I. Kolodkina ${ }^{1}$, A.V. Arutyunov' ${ }^{2}$, T.S. Kochkonyan ${ }^{3}$, \\ A.A. Ovsyannikova', V.L. Popkov', O.N. Risovannaya ${ }^{4}$, \\ A.G. Arutyunova ${ }^{5}$, E.T. Doeva' ${ }^{1}$ D.A. Domenyuk ${ }^{6}$
}

\begin{abstract}
${ }^{1}$ Department of propaedeutics and prevention of dental diseases, Kuban State Medical University, Ministry of Healthcare of Russian Federation, M. Sedina str., 4, Krasnodar, Russia, 350063. E-mail: corpus@ksma.ru, tel: +78612680210

${ }^{2}$ Department of Therapeutic Dentistry, Kuban State Medical University, Ministry of Healthcare of Russian Federation, M. Sedina str., 4, Krasnodar, Russia, 350063.E-mail: corpus@ksma.ru, tel: +78612680210 ${ }^{3}$ Department of Prosthetic Dentistry, Kuban State Medical University, Ministry of Healthcare of Russian Federation, M. Sedina str., 4, Krasnodar, Russia, 350063. E-mail: corpus@ksma.ru, tel: +78612680210 ${ }^{4}$ Department of Dentistry Faculty of Advanced Studies and Retraining Specialists, Kuban State Medical University, Ministry of Healthcare of Russian Federation, M. Sedina str., 4, Krasnodar, Russia, 350063. E-mail: stomatologia.fpk@gmail.com, tel: +7861 2680210 ${ }^{5}$ Department of Pediatric Dentistry, Orthodontics and Maxillofacial Surgery, Kuban State Medical University, Ministry of Healthcare of Russian Federation, M. Sedina str., 4, Krasnodar, Russia, 350063. E-mail:kaf-detstom@yandex.ru, tel: +7861 2680210 ${ }^{6}$ Department of general practice dentistry and child dentistry, Stavropol State Medical University, Ministry of Healthcare of Russian Federation, 310, Mira Street, Stavropol, Russia 355017. E-mail: domenyukda@mail.ru, tel: +79188701205
\end{abstract}

\section{INTRODUCTION}

Of numerous reasons that affect the reliability and durability of restoration, the oral hygiene level is among the top ones [1,2]. Poor oral care is known to be a factor facilitating cariogenicity $[3,4,5,6,7,8]$. At the same time, improper oral hygiene can also cause complications occurring after restoration (hyperesthesia, edge permeability and edge adaptation, secondary caries) [9]. The patient's hygiene status is of special importance when there are light-cured composite materials involved.

Currently, there is a large selection of chemical and light-cured composites. Different materials have certain advantages and disadvantages. All filling materials have their own features that determine the restoration reliability and aesthetics $[10,11]$. The major properties for composite materials include strength, polymerization,

\author{
Article history: \\ Received 11 February 2019 \\ Received in revised form 18 March 2019 \\ Accepted 22 March 2019
}

ABSTRACT - THE AIM OF INVESTIGATION was to study the histological and immunohistochemical picture of periodontal tissues in experimental animals when exposed to the light-cured nanohybrid dental restorative material Restavrin with and without Easy Glaze coating. Materials AND METHOds. A cariogenic model in the experiment on animals ( 50 rats), an artificial defect of hard tissues (Black class V) was created with further filling with the nanohybrid material Restavrin + sealant Easy Glaze ( $1^{\text {st }}$ main group - P-1), Restavrin ( $2^{\text {nd }}$ main group - P-2) and microhybrid composite Filtek Z-250 (control group). RESULTS. In the study of periodontal segments in the comparison group and the group P-1, morphological differences were not determined. In the study of biopsy specimens taken from animals of the control group and group P-2, a number of dystrophic and inflammatory changes were detected. An immunohistochemical study of biopsy specimens in the comparison group and the P-1 group did not establish differences in the qualitative signs of immunocytes from their number and localization. In the study of biopsy specimens taken from animals of the control group and group P-2 there was a significant increase in the number of $\mathrm{HLA}-\mathrm{DR}^{+}$and $\mathrm{CD}^{+}$cells in the mucosal lamina propria; a slight increase in $\mathrm{CD}^{+}$cells in the mucosa itself. In the epithelium of animals in the control group and the group P-2, a decrease in $\mathrm{CD}^{+}$cells was recorded compared with the group of intact animals and the group P-1. In a number of drugs in animals of the control group and group P-2 there was a significant infiltration of $\mathrm{CD}_{16} 6^{+} \mathrm{NK}$ cells, $\mathrm{CD} 20^{+} \mathrm{B}$ cells of the papillary layer of the mucous membrane itself, $\mathrm{CD} 23^{+}$cells were observed, however, there was no pronounced infiltration of $\mathrm{CD}_{16} 6^{+}, \mathrm{CD} 20^{+}$tissues and cells. CONCLUSION. Established in the course of the experiment on animals, the facts of the expression of molecules on gingival cells, antigen-presenting dendritic cells at different stages of maturation, B-lymphocytes carrying a low affinity receptor for immunoglobulin $\mathrm{E}$, in our opinion, can be associated with a violation of periodontal contact during filling of artificially created solid defects tissues, as well as the penetration of aggressive microflora into the deeper layers of the mucous membrane and periodontal due to the low level of hygiene and lack of solid food in the diet otnyh. In addition, the lack of infiltration of the studied toothgingival segments of rats by $\mathrm{CD} 23^{+}$cells may indirectly indicate the hypoallergenicity of the restorating material Restavin.

KE Y W O RDS - dental filling material Restavrin, sealant Easy Glaze, microhybrid composite Filtek Z-250, hypoallergenic. 
elasticity modulus, wear resistance, thermal expansion, and hardness $[12,13]$.

The constantly developing market of dental materials offers new filling materials and even new groups of materials $[14,15,16]$. One of such materials is the light-cured nanohybrid dental filling material Restavrin manufactured in Russia (Technodent).

The issue of filling material functional properties, aesthetics and durability under poor hygiene conditions, as well as its impact on the oral cavity tissues, appears to be of considerable interest $[17,18]$.

To investigate the histological and immune-histoAim of study: chemical profile of periodontal tissues in experimental animals when exposed to the light-cured nanohybrid dental restorative material Restavrin used with and without the Easy Glaze sealant.

\section{MATERIALS AND METHODS}

The experiment implied modeling a cariogenic situation in the oral cavity involving white rats (the experiment was conducted on the premises of the Research \& Development Department of the Kuban State Medical University, Ministry of Health, Russia. The animals were selected based on the same type of housing conditions (limited cell area), yet with different diets and types of food, which served basis for the caries development. A total of 50 animals (six months old) were used through the experiment (Table 1).
After the cariogenic situation modeling was completed under general anesthesia (viz. intraperitoneal thiopental anesthesia, $0.1 \mathrm{ml}$ of $5 \%$ sodium thiopental per 100 grams of animal weight) a spherical bur was used to go 2-3 $\mathrm{mm}$ under the gum thus making an artificial defect of hard tissues in the cervical area of mandibular incisors from the vestibular and lingual sides. Subject to the research plan, the created hard tissues teeth defects were filled with the nanohybrid material Restavrin + the Easy Glaze sealant ( $1^{\text {st }}$ main group, $\mathrm{R}-1, \mathrm{n}=15$ ), Restavrin ( $2^{\text {nd }}$ main group, $\mathrm{R}-2$, $\mathrm{n}=15)$ and the microhybrid composite Filtek Z-250 (3M ESPE) (control group, $\mathrm{n}=10$ ). Besides, immunohistochemical studies were carried out in the comparison group (intact animals, $\mathrm{n}=10$ ). 30 days later, with anesthesia, the animals had their dentoalveolar segments cut to be further fixed in a buffered formalin $10 \%$ solution, and decalcified in a nitric acid $20 \%$ solution. After processing through ascending alcohols the samples were embedded in paraffin. The histological sections were stained with hematoxylin-eosin, by Mallory and Masson. The morphometric examinations were performed using the Video-Test-Morphology 5.1 for Windows software. The identification of the subpopulation markers for immunocytes of the dentoalveolar segments tissues was performed through indirect biotin-extravidine-peroxidase method. For the study control, reaction was performed with normal mouse serum, which has no staining, rather than with primary antibodies.

Table 1. Comparative features of the animal groups involved in the study, $(M \pm m)$

\begin{tabular}{|c|c|c|c|c|c|}
\hline Animal groups & $\begin{array}{l}\text { Number of } \\
\text { animals }\end{array}$ & Distribution by gender & $\begin{array}{l}\text { Age of introduction to } \\
\text { the experiment }\end{array}$ & $\begin{array}{l}\text { The average body weight } \\
\text { at the beginning of the } \\
\text { experiment }\end{array}$ & $\begin{array}{l}\text { The duration of the } \\
\text { experiment }\end{array}$ \\
\hline Comparison group & 10 & 5 males, 5 females & 6 months \pm 3 days & $230,5 \pm 20,5 \mathrm{gm}$ & 60 days \\
\hline First group & 15 & 7 males, 8 females & 6 months \pm 3 days & $230,5 \pm 20,5 \mathrm{gm}$ & 60 days \\
\hline Second main & 15 & 8 males, 7 females & 6 months \pm 3 days & $225,5 \pm 22,5 \mathrm{gm}$ & 60 days \\
\hline Control group & 10 & 5 males, 5 females & 6 months \pm 3 days & $225,5 \pm 24,5 \mathrm{gm}$ & 60 days \\
\hline
\end{tabular}

The animals were assigned to groups in view of having an equal representation of male and female animals in each group as well as based on the limited average mass deviations (no more than 10\%).

The caries model was developed within 1 month by keeping the animals of the main groups on the cariogenic Stephan diet. To boost the simulation, the rats' diet mentioned above was enriched with sunflower oil $(2 \mathrm{ml}$ per animal). The animals of the control group and of the comparison groups were kept on the standard balanced diet including solid food (cereals) and water with no limit.
The experiments were carried out following the International Principles of the European Convention for the Protection of Vertebrate Animals Used for Experiments and Other Scientific Purposes (Strasbourg, 1986), Common Ethical Principles of Animal Experiments (Russia, 2011), subject to the principles of good laboratory practice (The national standard Principles of Good Laboratory Practice GOST R 53434-2009) and the positive conclusion from the Ethics Committee of the Kuban State Medical University, Ministry of Health of Russia. Statistical data processing was 
performed using Statistica 6.0. Data treatment was carried out through attribute control charts and nonparametric criteria testing.

\section{RESULTS AND DISCUSSION}

As the experimental study showed, in the comparison group (intact animals, $\mathrm{n}=10$ ), the basal layer of the buccal epithelium included cells of mainly prismatic shape with basophilic cytoplasm and nuclei located in 1-3 rows. The granular layer itself consisted of several rows of flattened cells with elongated hyperchromic nuclei, while the epithelium mucous membrane appeared as papillae penetrating deep into the buccal epithelium. Cells near the basement membrane had shortened processes and resembled HLA-DR ${ }^{+}$cells located in the spinous and granular layers, which also had a process-like structure. The obtained data on the autokinesis of antigen-presenting dendritic cells from capillaries straight through the basement membrane into the entire epithelium thickness, and then back through the lymphatic bed to the secondary lymphoid organs, is within the norm. The results in the comparison group revealed that CD3-positive cells were found in small quantities in the spinous layer, could be occasionally detected in the papillary layer of the proper mucous plate (lamina propria), and sometimes - in the reticular layer. The tissue distribution of the detected $\mathrm{CD}^{+}$ cells, which were represented by the $\mathrm{CD}^{+}{ }^{+}$and $\mathrm{CD} 8^{+}$ subpopulations (where $\mathrm{CD}^{+}$were, actually, the helpers/inductors, and the $\mathrm{CD}^{+}-$the cells), in general, corresponded to the distribution specific of $\mathrm{CD}^{+}$cells. $\mathrm{CD}^{+}$cells, in turn, were localized in a small amount in the spinous or basal epithelium layers, while $\mathrm{CD}^{+}$cells - only in the basal layer and, significantly less often, in the adjacent rows of the spinous layer. A number of prepatations revealed the presence of $\mathrm{CD} 8^{+}$cells on the tops of the interdental papillae, while $\mathrm{CD} 4^{+}$cells were identified between the papillae of the proper mucous plate, in an amount of 3-5 per microscope field.

$\mathrm{CD} 20^{+}$cells were observed in 2 preparations only, while the majority of immunocytes were represented by antigen-presenting HLA-DR ${ }^{+}$cells and a subpopulation of T cells (Fig. 1).

Consequently, in the comparison group, $\mathrm{CD} 23^{+}$ cells (B-lymphocytes mediating the low-affinity receptor for immunoglobulin E) basically were not to be observed. The papillary layer contained HLA-DR ${ }^{+}$cells, from 6 to 9 per one field, which lined up along the basal membrane. An immune-histochemical examination of biopsy specimens obtained in group R-1 (Restavrin + Easy Glaze sealant) revealed the impaired keratinosation of the keratinocytes, which manifested itself as isolated parakeratosis. Vacuolar cell degeneration was mainly observed in the epithelium spinous layer; moderate round cell infiltration was mainly recorded in the lamina propria papillary layer. Collagen fiber thickening was observed in the reticular layer only. In the spinous epithelium, HLA-DR ${ }^{+}$cells were detected near the basal membrane, as well as in the papillary and reticular layers in an amount of 5 to 7 per one field (Fig. 2).

The number of $\mathrm{CD}^{+}$cells in the preparations of this group increased if compared with the norm, while 3 to 5 cells per 1 field were localized in the spinous layer, near the basal membrane, and from 2 to 3 - in the mucosa papillary layer. $\mathrm{CD}^{+}$cells, in turn, in an amount of 3 to 6 per one field were located in the main, spinous and basal epithelium layers as well as along the basal membrane of the proper mucous plate. Special mention is to be made that the number of cells decreased significantly compared to the intact animals group, whereas specific CD $8^{+}$cells ( 4 to 6 per one field) were located both in the basal and in the adjacent spinous layer. The epithelial layer of the mucous membrane revealed no changes in the number of $\mathrm{CD} 16^{+}$cells, and the number of $\mathrm{CD} 20^{+}$cells which mediate the B-cell population was also not significantly different from the similar index in the comparison group (intact animals) where $\mathrm{CD} 23^{+}$cells were detected (Fig. 3).

The biopsy specimens of the R-1 group neither morphologically nor immune-histochemically confirmed the signs of chronic nonspecific inflammation involving cellular and humoral immunity. As the results of the study in the R-2 group showed, immuno-histological preparations featured moderate transformations in the morphological structure of the periodontal disease manifested as mild keratinosation disturbance. Actually, the parakeratosis manifestations were significantly less prominent than in the biopsy specimens of the R-1 group. Edema and round-cell infiltration of the proper mucous plate were detected in a small part of the biopsy specimens. Collagen fibers were visualized in the reticular layer, they had a predominant view of slightly thickened and compacted plates, while no round-cell infiltration was detected. In the R-2 group, $\mathrm{CD}^{+}$cells were detected near the basal membrane; their number in the mucosal epithelium did not change compared with this index in the comparison group and the R-1 group; however, a significant number of $\mathrm{CD}_{4}{ }^{+}$cells were identified ( 3 to 9 per one field). The total number of $\mathrm{CD}^{+}{ }^{+}$cells located directly near the basal membrane and in the papillary mucosal layer, if compared with the R-1 group, did not change and ranged from 4 to 6 per one microscope field (Fig. 4).

$\mathrm{CD} 8{ }^{+}$cells were located in the depth of the spinous layer and near the basal membrane (Fig. 5). 


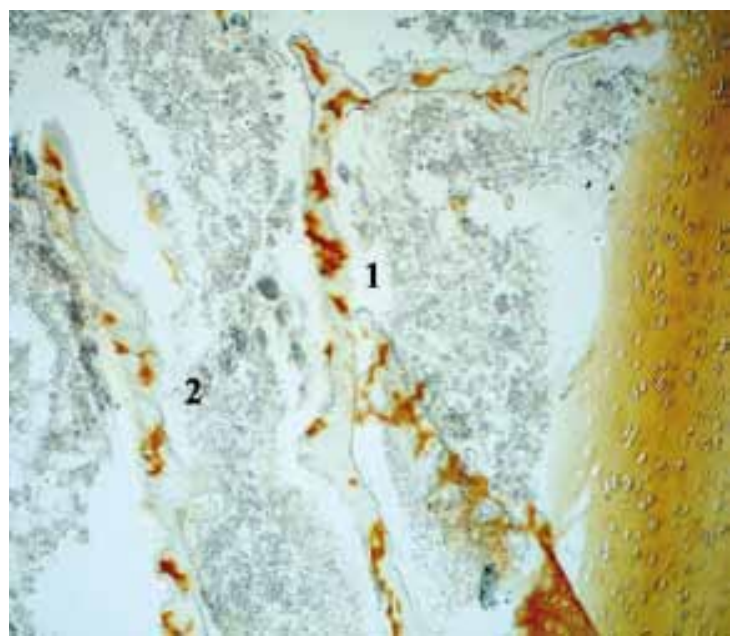

Fig. 1. Micro-photograph of the intact papilla fragment of an animal from the comparison group, $n=10$. Cryostat section; mcAT1-antiHLA-DR; AES development; contrasting - Mayer's Hemalum; 0 c. 15, 0bj. 60. Numerical designation: 1. HLA-DR+ cells in the basal membrane thickness; 2 . HLA-DR+ papillary mucosal cells.

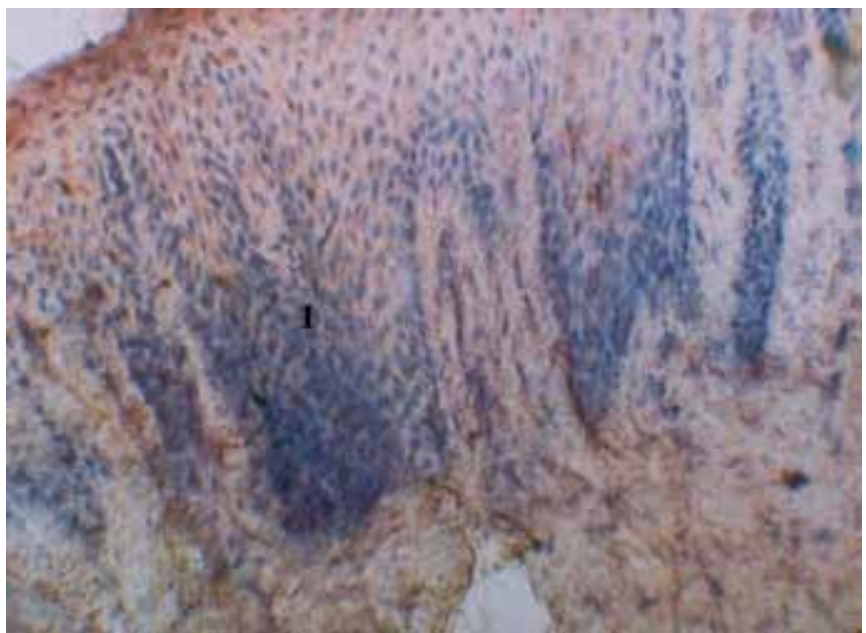

Fig. 3. Micro-photograph of a gingival papilla fragment in group $R-1, n=15$. Cryostat section; mcAT1-anti-CD20; AES development; Contrast — methylene blue; 0c. 15, 0bj. 60. Numerical designation: 1. CD20+ cells

It should be noted that there were basically no $\mathrm{CD} 23^{+}$and $\mathrm{CD} 16^{+} \mathrm{NK}$ cells, while the number of $\mathrm{CD} 20^{+}$cells was insignificant ( 1 to 3 per a field), which helps describe the morphological compartment of the isolated tissues as specific. The expression of HLADR molecules, which was particularly evident in the mucous membrane, was also observed in cells located in the spinous layer above the interdental papillae tops, near the cells of the basal layer, in an amount of 8 to 15 per microscope field (Fig. 6).

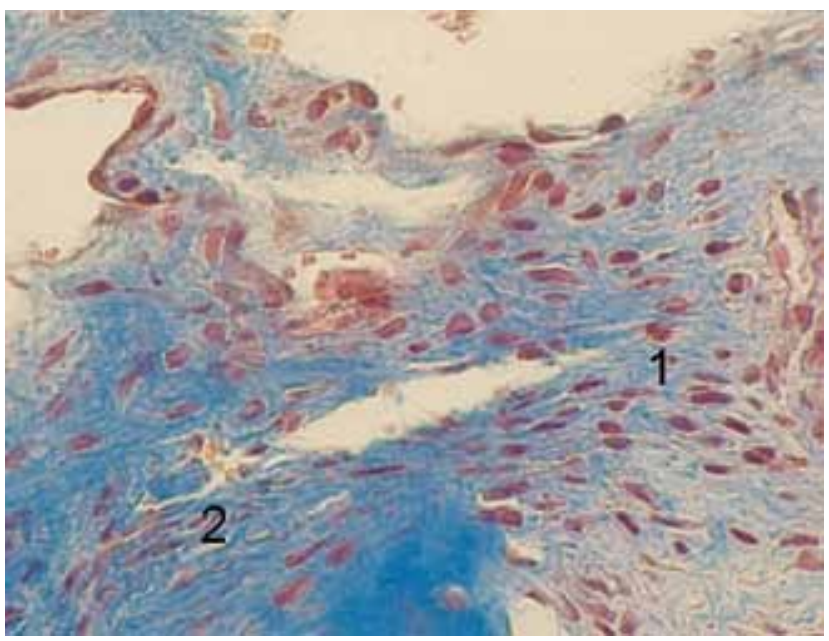

Fig. 2. Micro-photograph of the papilla fragment of an animal from group $R-1, n=15$. Cryostat section; mCAT1-anti-HLA-DR; AES development; Contrast - methylene blue; 0c. 15, 0bj. 60. Digital expression: 1. HLA-DR+ cells of the epithelium spinous layer; 2 . HLA-DR+ cells of the mucosa

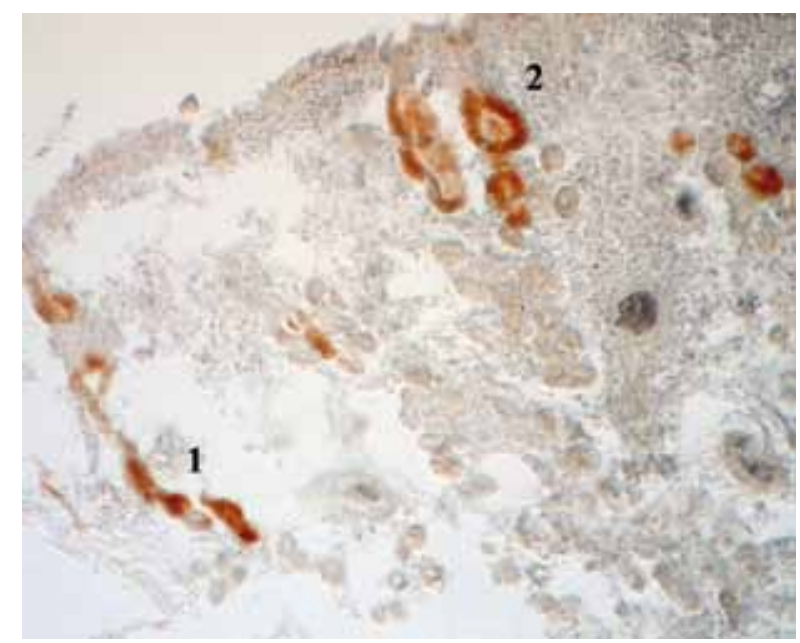

Fig. 4. Micro-photograph of a gingival papilla fragment in group $R-2, n=$ 15. Cryostat section; mcAT1-anti-CD4; AES development; contrasting Mayer's Hemalum; Oc. 15, 0bj. 60. Numerical designation: 1. CD4+ cells of the epithelium spinous layer; 2 . $C D 4^{+}$cells of the mucosal papillary layer

Besides, infiltration of the papillary layer of proper mucous plate the $\mathrm{CD}^{+}$cells in an amount of 5 to 10 per microscope field was registered. The number of $\mathrm{CD} 3$ positive cells was reduced in the epithelium of the proper mucous plate ( 2 to 4 per one field). When studying the biopsy specimens of the control group (Filtek Z-250), parakeratosis were observed in up to $2 / 3$ of the studied preparations (increased keratinocyte keratinization) and mild vacuolar dystrophy. Spongiosis was observed in $1 / 3$ of the preparations. The 


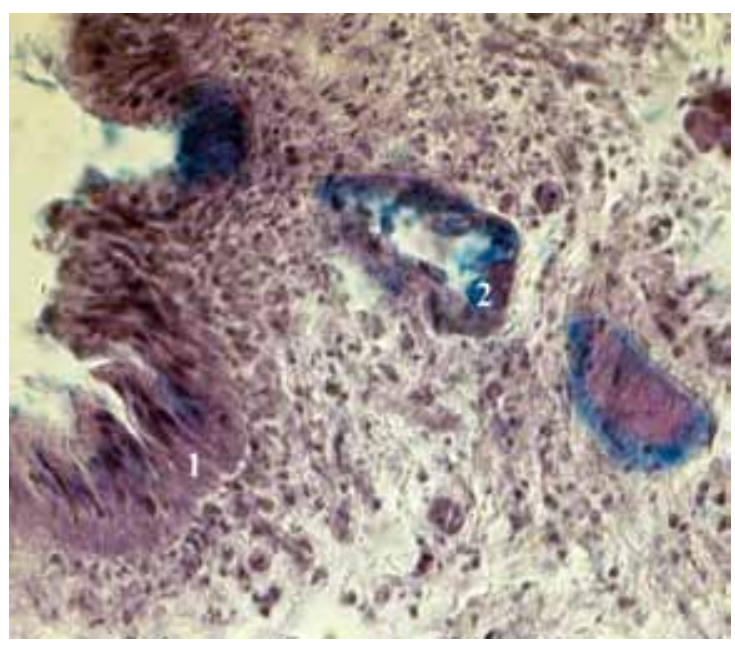

Fig. 5. Micro-photograph of a gingival papilla fragment in group $R-2, n=15$. Cryostat section; mCAT1-anti-CD8; AES development; contrasting - Mayer's Hemalum; 0c. 15, 0bj. 60. Numerical designation: 1. CD8 ${ }^{+}$spinous layer cells; 2. CD8 ${ }^{+}$basal layer cells

papillary layer at the peripheral vessels mainly localized HLA-DR+ cells ( 5 to 12 per one field). Moderate $\mathrm{CD}^{+}$cells infiltration of the epithelial layer was also observed ( 2 to 5 per one field) and partly of the mucous papillary layer ( 5 to 9 per 1 field) (Fig. 7).

$\mathrm{CD} 4^{+}$cells located in the spinous layer, and less (1 to 3 per one field) in the epithelium basal layer; their number basically revealed no change compared to the intact periodont in the reticular and papillary layers of the lamina propria. CD8+ cells were also observed in the papillary and reticular layers of the proper mucous plate ( 4 to 9 per one field).

\section{CONCLUSIONS}

1. The immune-histochemical study revealed no qualitative difference between the number of immune cells in the biopsy specimens of the gingival papillae in intact animals and animals of the R-1 group (Restavrin + Easy Glaze sealant). A morphological study of gingival papilla biopsy specimens in the control group (Filtek Z-250) and the R-2 group (Restavrin) revealed signs of an inflammatory process characterized by an increase in the number of HLA-DR ${ }^{+}, \mathrm{CD}^{+}, \mathrm{CD}^{+}$ cells in the epithelium along with a reduced number of HLA-DR ${ }^{+}, \mathrm{CD}^{+}$cells and an unchanged number of $\mathrm{CD}^{+}, \mathrm{CD}^{+} 6^{+}, \mathrm{CD} 20^{+}, \mathrm{CD} 23^{+}$cells in the lamina propria among the dentoalveolar segments.

2. Objective facts of molecules expression on the studied cells, as well as the revealed cytological signs manifested as antigen-presenting dendritic cells at different maturation stages, the presence of B-lymphocytes carrying a low affinity receptor for

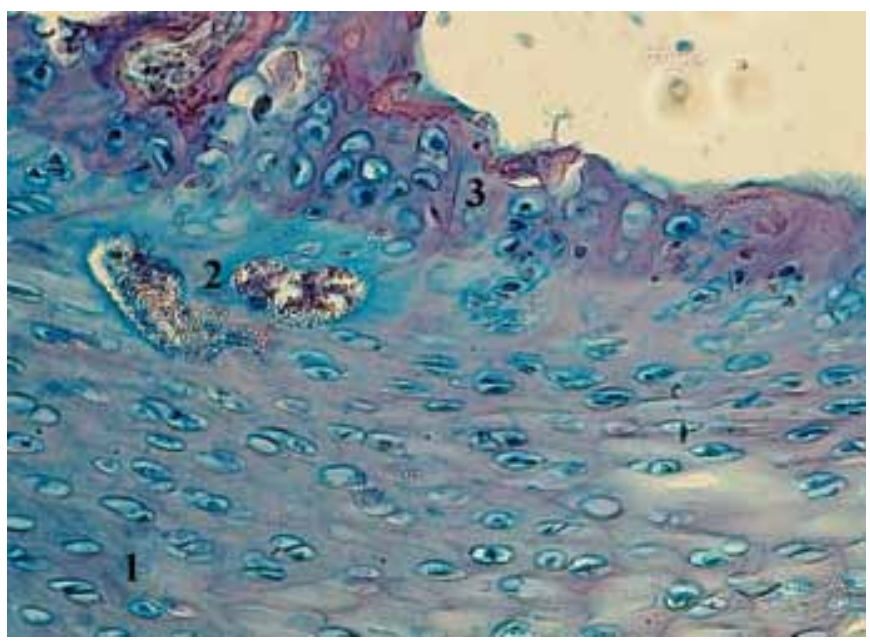

Fig. 6. Micro-photograph of a papilla fragment in group $R-2, n=15$. Cryostat section; mCAT1-HLA-DR; AES development; contrasting - Mayer's Hemalum; Oc. 15,

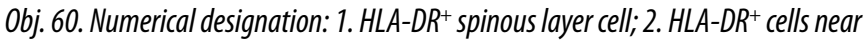
the basal membrane; 3. HLA-DR+ cells of the mucous membrane

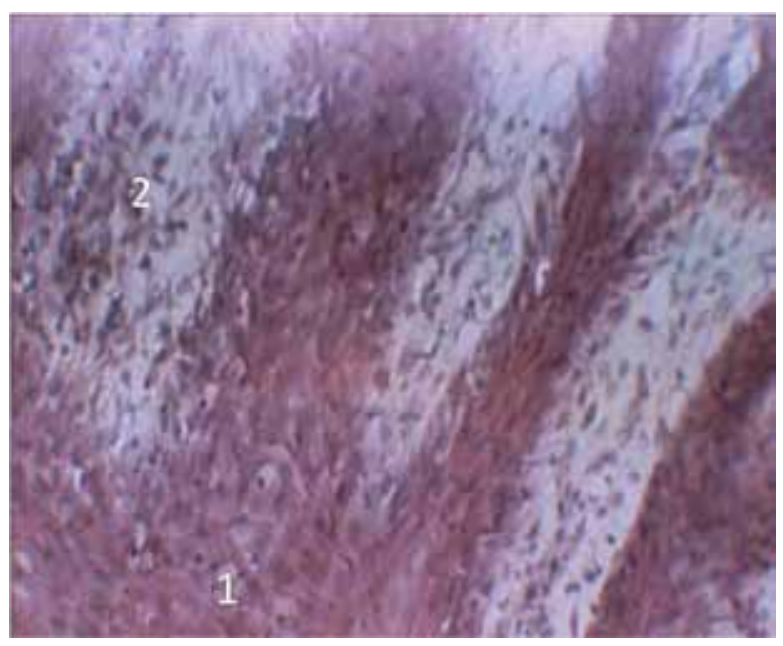

Fig. 7. Micrograph Micro-photograph a gingival papilla fragment in the control group, $n=10$. Cryostat section; hematoxylin and eosin staining; Oc. 15, 0bj. 60. Numerical designation: 1. vacuolar dystrophy; 2. papillary layer lymphoid infiltration

immunoglobulin E - indicate disturbed intercellular cooperation and penetration of pathogenic microflora into the deeper layers of mucous membrane and periodont due to poor hygiene and lack of solid food in the experimental animals' diet. The absence of intercellular CD23 $3^{+}$infiltration in the studied biopsy specimens is an indirect indication of hypoallergenic properties of the Restavrin and Restavrin + Easy Glaze sealant used in the experiment. 


\section{REFERENCES}

1. MakeeVA I.M., Babina K.S. Reproducibility of oral hygiene indices. Farmateka. 2013; 4: 11-13.

2. DAVydov B.N., Domenyuk D.A., BYKov I.M., IVCHENKo L.G., DMitriENKo S.V. Modern possibilities of clinical, laboratory, X-ray studies in preclinical diagnosis and prediction of the risk of developing periodontal diseases in children with diabetes mellitus type one. Part I. Periodontology. 2018; Vol. XXIV; 3-24 (88): 4-11. (In Russ.). DOI: 10.25636/ PMP.1.2018.3.1.

3. Fattal R.K., Ammaev M.G., Melekhov S.V. Effectiveness of modern microinvasive methods of treatment of initial caries of teeth depending on the level of oral hygiene of the patient. Dental Forum. 2015; 1(56): 5-8.

4. Domenyuk D.A., Davydov B.N., GilmiYarova F.N., Porfyriadis M.P., Budaychiev G.M.-A. Optimization of pathogenetic therapy of caries of teeth in children sufficiating first type of diabeted diabetes, taking into account the methodological principles of personalized medicine (Part I). The Dental Institute. 2018; 81(4): 81-83. (In Russ.)

5. Bykov I.M., GilmiYarova F.N., Domenyuk D.A., DMitrienko S.V., IVANYUTA S.O., BUDAYChIEV G. M-A. Evaluation of cariogenic situation in children with type 1 diabetes mellitus given the mineralizing potential of saliva and enamel resistance. Kubanskij nauchnyj medicinskij vestnik. 2018; 25(4): 22-36. (In Russ., English abstract). DOI: 10.25207 / 1608-62282018-25-4-22-36.

6. Domenyuk D.A., Zelensky V.A., Karslieva A.G., BAzIKov I.A. Assesment of microbiological status in children with abnormalities of dental system by the results bakteriologis of molecular genetic research. Medical Bulletin of the North Caucasus. 2014; T. 9; 4(36): 344-348. (In Russ., English abstract). DOI: $10.14300 /$ mnnc.2014.09096.

7. BAZIKov I.A., Domenyuk D.A., Zelensky V.A. Semiquantitative evaluation of caries microflora in patients with dental and alveolar abnormalities and different severity of morphofunctional disturbances. Medical Bulletin of the North Caucasus. 2015; T. 10; 3(39): 238-241. (In Russ., English abstract). DOI: $10.14300 /$ mnnc.2015.10055.

8. Domenyuk D.A., Zelensky V.A., DMitrienko S.V., Anfinogenova O.I., Pushkin S.V. Peculiarities of phosphorine calcium exchange in the pathogenesis of dental caries in children with diabetes of the first type. Entomology and Applied Science Letters. 2018; 5(4): 49-64.

9. Tokmakova S.I., Bondarenko O.V., Chechun N.V., Voblova T.V., Zhilenko O.G. Assessment of the quality of the marginal fit of the fillings with various methods of preparation in the treatment of dental caries. Zhurnal nauchnykh statej Zdorov'e i obrazovanie v XXI veke. 2017; 19(4): 53-55.

10. Adamchiк A.A. Evaluation of the polymerization of the composite. Kubanskij nauchnyj medicinskij vestnik. 2015; 1(150): 7-11.
11. ZhDANOv S.E., LUKINYKH L.M., ZhDANOVA M.L. Improving the way of aesthetic restoration of teeth. Sovremennye tehnologii v medicine. 2013; 5(2): 93-97.

12. Starodubova A.V., Vinnichenko Yu.A., PoyUROVSKAYA I.YA., RuSANOV F.S. Evaluation of the main physicomechanical properties of composite materials for the restoration of teeth by a direct method when combining several layers of composites differing in the consistency of pastes. Rossijskij stomatologicheskij zhurnal. 2017; 21(3): 132-135.

13. Domenyuk D.A., Zelenskiy V.A., Porfiriadis M.P., Bazikov I.A., GilmiYarova F.N. Study of the spectrum of dental composites biological activity in model experiments in vitro. Medical Bulletin of the North Caucasus. 2016; Vol. 11; 2: 179-183. (In Russ., English abstract). DOI: 10.14300/mnnc.2016.11031.

14. Primerova A.S., Mitronin A.V., Chunikhin A.A. Modern composite materials for the restoration of the teeth of the chewing group, their properties and development trends. Cathedra. Stomatologicheskoe obrazovanie. 2011; 36: 56-59.

15. Morozov A.N., Popova T.A., Pshenichnikov I.A., Primacheva N.V., BobeshKo M.N., Zaido A. Effectiveness of using a universal bioactive bonding system in the treatment of caries. Nauchno-meditsinskij vestnik Tsentral'nogo Chernozem'ya. 2015; 62: 66-69.

16. Tsarev V.N., Trefilov A.G., Kleimenova G.A., LEVKIN A.V. Spatio-temporal model of the formation of the biofilm of the oral cavity: the interrelation of the processes of primary adhesion and microbial colonization. Dental Forum. 2011; 5(41): 126-131.

17. Lyovkin A.V., Grinin V.M. Current requirements for dental composite materials used for permanent fillings. Stomatologiya dlya vsekh. 2013; 4: 68-69.

18. Kutsevlyak V.F., Veligorya I.E., Lyubchenko OV, Pushkar L.Yu., Tsyganova N.B., PolyaKova S.V., IVANOV A.E., Sirota O.N., BozhKo K .V., GryshChenko V.V., Tsyganova I.V. Domestic flowing composite in the clinic of therapeutic dentistry. Stomatologiya. Estetika. Innovatsii. 2018; 1: $75-81$. 